Galloway, D. J. (1998a) Joseph Hooker, Charles Knight, and the commissioning of New Zealand's first popular flora: Hooker's Handbook of the New Zealand Flora (1864-1867). Tuhinga 10: 31-62.

Galloway, D. J. (1998b) Studies on the lichen genus Sticta (Schreber) Ach.: V. Australian species. Tropical Bryology 15: 117-160.

Krempelhuber, A. von (1876) Neue Beiträge zur Flechten-Flora Neu Seelands. Verhandlungen der Zoologisch-Botanischen Gesellschaften in Wien 26: 447-460.

D. J. Galloway ${ }^{\star}$

${ }^{\star}$ Landcare Research New Zealand Ltd, Private Bag 1930, Dunedin, New Zealand.

\title{
MYCOBIONT-SPECIFIC PCR PRIMERS FOR THE AMPLIFICATION OF NUCLEAR ITS AND LSU rDNA FROM LICHENIZED ASCOMYCETES
}

Lichen thalli are composed of several genetically distinct organisms: a fungus, and one or several green algal or cyanobacterial species. Any DNA amplification process from lichen thalli must minimize the risk of targeting the wrong DNA. A simple way to achieve this is to use polymerase chain reaction (PCR) primers with enhanced specificity for the lichen mycobiont. Mycobiontspecific PCR primers for the nuclear small subunit (SSU) of the ribosomal DNA (rDNA) were designed by Gargas \& Taylor (1992), and have enabled several investigations into lichen evolution and higher-level phylogeny (e.g. Gargas et al. 1995; Wedin et al. 1998). The SSU rDNA is, however, not variable enough for studies on lower taxonomic levels (Wedin \& Döring 1999). Within the nuclear ribosomal gene cluster, the internal transcribed spacers (ITS) region (ITS1 and/or ITS2) has been extensively used for lower level phylogenies, species delimitation, and population studies in nonlichenized fungi, with some recent examples from lichen studies (e.g. Lohtander et al. 1998; Arup \& Grube 1998).

Only a few fungal-specific primers, primarily designed for studies of mycorrhiza, are available for ITS amplifications from lichens (ITS1F, Gardes \& Bruns 1993; NL6A, Egger 1995). In our experience, amplification of the ITS region using these primers or some of the non-green algal primers located in the SSU rDNA, is still often non-specific with poor or multiple products. The nuclear large subunit rDNA (LSU), although more variable than the SSU, and extensively used for higher- and lower-level phylogenies of basidiomycetes and yeasts, have not yet been widely utilized in studies of ascomycete lichens. This is most likely due to the lack of suitable, fungal-specific PCR primers, and lack of relevant LSU sequence data in public databases. In order to enable studies into ecology and lower-level phylogeny of lichen-forming ascomycetes, we have designed specific PCR primers that do not amplify the ITS and LSU rDNA of lichen algae, and are located in the $5^{\prime}$ part of the LSU.

The primers were constructed using a manually adjusted MegAlign alignment (LaserGene, DNASTAR Inc.) of LSU sequences of representative 
ascomycetes (GenBank J01355, X70659), basidiomycetes (L14067, U62964, Z19136), and green algae including 8 lichen photobionts (D17810, Z95378Z95385), together with $c$. 30 newly produced lichen mycobiont LSU sequences from the orders Agyriales, Gyalectales and Lecanorales. Regions conserved within the (eu-)ascomycetes and distinct from green algae were identified, and primer sequences designed (Table 1, Fig. 1). Advanced BLAST-searches in GenBank confirmed the potential specificity of the primers. The primer nomenclature is similar to the suggestion by Gargas \& DePriest (1996). The name gives the position of the $3^{\prime}$ base of the primer according to Saccharomyces cerevisiae (J01355).

Total DNA was extracted from lichen thalli using the Qiagen DNeasy Plant Mini Kit. The PCR amplifications were performed in $25-\mu l$ reaction volumes using 0.75 units AmpliTaq Gold (Perkin-Elmer) with the supplied buffer, 12.5 pmol of each primer, and final concentrations of 1.5 (up to 3.0 ) $\mathrm{mM}$ $\mathrm{MgCl}_{2}$ and $200 \mu \mathrm{M}$ each dNTP. DNA concentrations were optimized with dilution series. The PCR reactions performed in a Omnigene Thermocycler (Hybaid) started with a 10 -min denaturation step at $95^{\circ} \mathrm{C}$, followed by 5 cycles of $95^{\circ} / 1 \mathrm{~min}, 53 \% 30 \mathrm{~s}, 72^{\circ} / 2 \mathrm{~min}$, and 35 cycles of $95^{\circ} / 1 \mathrm{~min}, 50 \% 20 \mathrm{~s}$, $72^{\circ} / 2 \mathrm{~min}$, and a final $10-\mathrm{min}$ extension step at $72^{\circ} \mathrm{C}$. Cycle sequencing was performed as described in Wedin \& Döring (1999).

The new primers have, in combination with the non-specific primers nu-SSU-1626-5' (Gargas \& DePriest 1996), LR0R, LR5, LR6, and LR9 (Cubeta et al. 1991; Vilgalys \& Hester 1990; R. Vilgalys website) successfully amplified the ITS region and parts of the LSU rDNA from DNA extractions of lichenised ascomycetes. The primer pairs nu-SSU-1626-5'/nu-LSU-136-3', LR0R/nu-LSU-401-3', nu-LSU-155-5'/LR5 and nu-LSU-155-5'/LR6, nu-LSU-362-5'/LR5 and nu-LSU-362-5'/LR6, nu-LSU-869-5'/LR9, and nu-LSU-871-5'/LR9 all gave clear and distinct amplification products, whereas nu-SSU-1626-5'/nu-LSU-355-3' resulted in faint products. Sometimes nu-SSU-1626-5'/nu-LSU-136-3' resulted in weak bands in addition to the main product. In order to ensure specificity, DNA extractions from cultures of common lichen photobionts (Coccomyxa solorinae var. bisporae UTEX 275, Trebouxia erici UTEX 911 and T. usneae UTEX 2235) have also been tested. They were suitable for PCR, as shown by successful amplification with non-specific primer combinations, but did not result in distinct products with any of the new primers under normal PCR conditions. When the DNA or $\mathrm{MgCl}_{2}$ concentrations were high the algal extractions sometimes gave faint bands, particularly with nu-LSU-362-5'/LR6. All PCR products obtained were of the expected size, or larger, indicating the presence of insertions in some taxa.

Several of the new primers have been tested in cycle sequencing reactions. Together with published primers the new primers have been used to amplify and sequence a number of species of the lichenized ascomycete orders Agyriales, Gyalectales and Lecanorales, and the specificity of the primers used for the PCR amplification has been verified by sequence alignment. Optimisation of the DNA and $\mathrm{MgCl}_{2}$ concentrations is recommended for critical samples, as well as testing of higher annealing temperatures and usage of pairs of specific primers. The new primers will significantly facilitate further 


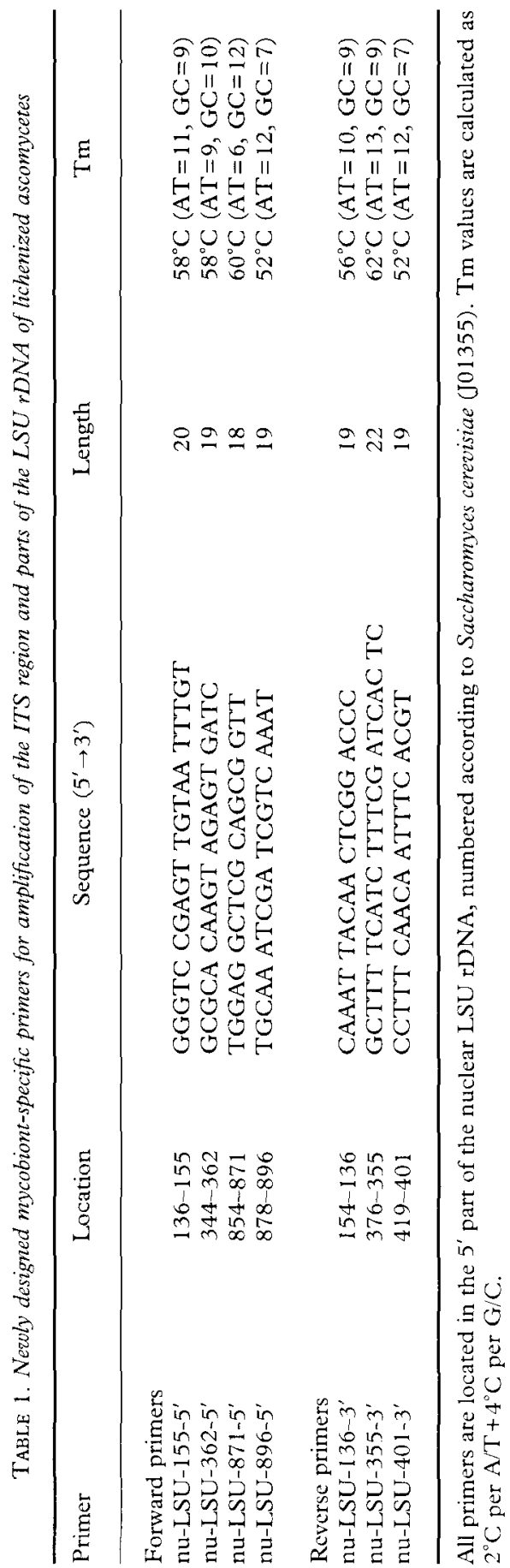




\begin{tabular}{|c|c|}
\hline $\begin{array}{l}\text { nu-LSU-155-5' } \\
\text { nu-LSU-136-3' } \\
\mathrm{Pa}, \mathrm{Ne} \\
\mathrm{Pi} \\
\mathrm{Neo} \\
\text { Lo } \\
\text { Tra } \\
\text { L. ter } \\
\text { T. arb } \\
\text { T. eri. }\end{array}$ & 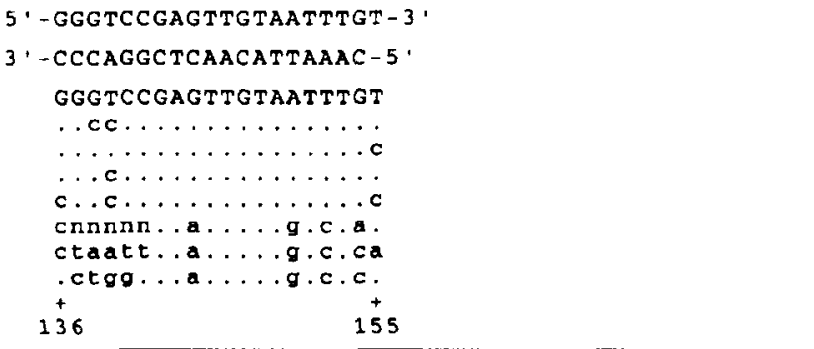 \\
\hline $\begin{array}{l}\text { nu-LSU-362-5' } \\
\text { nu-LSU-355-3' } \\
\text { Pa, Pi, Neo, Gy, Tra } \\
\text { Lo } \\
\text { Ne } \\
\text { L. ter, T. arb } \\
\text { T. eri }\end{array}$ & 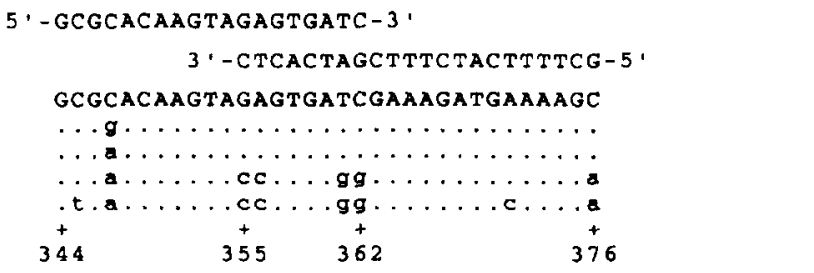 \\
\hline $\begin{array}{l}\text { nu-LSU-401-3' } \\
\mathrm{Pa}, \mathrm{Pi}, \mathrm{Neo}, \mathrm{Lo}, \mathrm{Ne}, \mathrm{Tra} \\
\mathrm{Gy} \\
\text { L. ter, T. arb, T. eri }\end{array}$ & 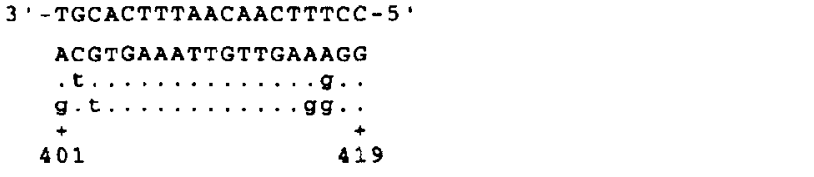 \\
\hline $\begin{array}{l}\text { nu-LSU-871-5' } \\
\text { nu-LSU-896-5' } \\
\mathrm{Pa}, \mathrm{Pi}, \mathrm{Neo}, \mathrm{Lo} \\
\mathrm{Ne} \\
\text { Gy } \\
\text { L. ter, T. arb, T. eri }\end{array}$ & 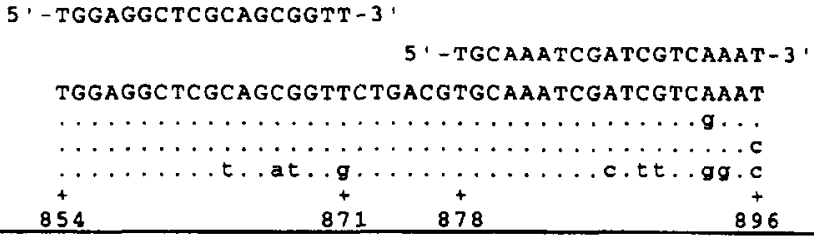 \\
\hline
\end{tabular}

FIG. 1. Priming sites in the LSU rDNA. Variation found within the priming sites is shown; representatives of the different types of mycobiont as well as photobiont sequences found are given. Primer and corresponding mycobiont sequences are shown in capital letters, differing bases in lower cases, identical bases by a dot. Location according to Saccharomyces cerevisiae (J01355). $\mathrm{Pa}=$ Parmelia saxatilis, $\mathrm{Ne}=$ Nephroma bellum, $\mathrm{Pi}=$ Pilophorus strumaticus, $\mathrm{Neo}=$ Neophyllis melacarpa, Lo=Lobaria pulmonaria, Tra = Trapelia involuta, Gy = Gyalecta jenensis, L.ter $=$ Leptosira terrestris (Z95378), T.arb = Trebouxia arboricola (Z95381), T.eri $=$ Trebouxia erici (Z95379).

investigations into lichen evolution, phylogeny, and ecology utilizing variable parts of the rDNA repeat.

This work received financial support from The NHM Museum Research Fund to M. Wedin.

\section{REFERENCES}

Arup, U. \& Grube, M. (1998) Molecular systematics of Lecanora subgenus Placodium. Lichenologist 30: 415-425.

Cubeta, M. A., Echandi, E., Abernethy, T. \& Vilgalys, R. (1991) Characterization of anastomosis groups of binucleate Rhizoctonia species using restriction analysis of an amplified ribosomal RNA gene. Phytopathology 81: 1395-1400. 
Egger, K. N. (1995) Molecular analysis of ectomycorrhizal fungal communities. Canadian foumal of Botany 73 (Suppl.1): 1415-1422.

Gardes, M. \& Bruns, T. D. (1993) ITS primers with enhanced specificity for basidiomycetes application to the identification of mycorrhizae and rusts. Molecular Ecology 2: 113-118.

Gargas, A. \& DePriest, P. T. (1996) A nomenclature for PCR primers with examples from intron-containing SSU rDNA. Mycologia 88: 745-748.

Gargas, A. \& Taylor, J. W. (1992) Polymerase chain reaction (PCR) primers for amplifying and sequencing nuclear 18S rDNA from lichenized fungi. Mycologia 4: 589-592.

Gargas, A., DePriest, P., Grube, M. \& Tehler, A. (1995) Multiple origins of lichen symbioses in fungi suggested by SSU rDNA phylogeny. Science 268: 1492-1495.

Lohtander, K., Källersjö, M. \& Tehler, A. (1998) Dispersal strategies in Roccellina capensis (Arthoniales). Lichenologist 30: 341-350.

Vilgalys, R. Conserved primer sequences for PCR amplification and sequencing from nuclear ribosomal RNA. Duke University, USA. Internet address http://www.botany.duke.edu/fungi/mycolab/ primers.htm.

Vilgalys, R. \& Hester, M. (1990) Rapid genetic identification and mapping of enzymatically amplified ribosomal DNA from several Cryptococcus species. Foumal of Bacteriology 172: $4238-4246$.

Wedin, M. \& Döring, H. (1999) The phylogenetic relationships of the Sphaerophoraceae, Austropeltum and Neophyllis (lichenized Ascomycota) inferred by SSU rDNA sequences. Mycological Research 103: 1131-1137.

Wedin, M., Tehler, A. \& Gargas, A. (1998) Phylogenetic relationships of Sphaerophoraceae (Ascomycetes) inferred from SSU rDNA sequences. Plant Systematics and Evolution 209: $75-83$.

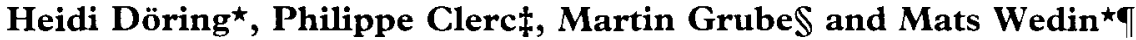

*Department of Botany, The Natural History Museum, Cromwell Road, London SW7 5BD, $\mathrm{UK}$.

¥Conservatoire et Jardin botaniques de la ville de Genève, 1, ch. de l'Impératrice, Case postale 60, CH-1292 Chambésy/GE, Switzerland.

\Institut für Botanik, Karl-Franzens-Universität, Holteigasse 6, A-8010 Graz, Austria.

TCorresponding address: Department of Ecology and Environmental Science, Umeả University, SE-901 87 Umeå, Sweden. 